\title{
Impact of the IL-18 gene polymorphism in response to antiviral therapy in chronic HCV genotype 4 patients
}

\author{
Mohamed Mandour ${ }^{[1]}$, Nader Nemr ${ }^{[2]}$, Rania Kishk ${ }^{[3]}$ and Eman Ahmed ${ }^{[4]}$
}

[1]. Department of Clinical Pathology, Faculty of Medicine, Suez Canal University, Ismailia, Egypt. [2]. Department of Endemic and Infectious Diseases, Faculty of Medicine, Suez Canal University, Ismailia, Egypt. [3]. Department of Microbiology and Immunology, Faculty of Medicine, Suez Canal University, Ismailia, Egypt. [4]. Department of Clinical Pharmacology, Faculty of Medicine, Suez Canal University, Ismailia, Egypt.

\begin{abstract}
Introduction: Interleukin (IL)-18 is a well-known major proinflammatory cytokine with broad biological effects. The major immunomodulatory functions of IL-18 include enhancing T cell and natural killer cell cytotoxicity. Serum levels of this cytokine were shown to increase in chronic hepatitis $\mathrm{C}$ patients compared to non-infected healthy people. An association between IL-18 gene promoter polymorphisms and pegylated interferon (PEG-IFN) and ribavirin treatment outcomes has been reported for individuals with chronic hepatitis C virus genotype 1 (HCV-1). In this study, HCV genotype 4 (HCV-4) patients were assessed for IL-18 gene polymorphisms and treatment outcomes or severity of liver disease because data concerning the impact of IL-18 gene polymorphisms on patients with HCV-4 infections are limited. Methods: This study included 123 chronic HCV-4 Egyptian patients and 123 apparently healthy volunteer blood donors who served as a control group. HCV genotyping was performed using the line probe assay. IL-18 genotyping was performed using the TaqMan Real-Time PCR method in all 246 patient and control samples. Results: In our study, all patients had HCV-4. IL-18 gene single nucleotide polymorphism (SNP) (-607C/A) genotype distributions and allele frequencies did not differ between HCV patients and normal healthy subjects or between patient groups when compared according to the therapeutic response. Moreover, the presence of an IL-18 SNP was not associated with histological disease severity. We conclude that the presence of the IL-18 SNP rs1946518 does not affect the outcome of chronic HCV-4 treatment in Egyptian patients. Conclusions: The IL-18 SNP rs1946518 does not affect response to treatment in chronic HCV-4 patients.
\end{abstract}

Keywords: IL-18. Sustained virological response. HCV genotype 4. Gene polymorphism.

\section{INTRODUCTION}

Hepatitis $\mathrm{C}$ virus (HCV), a member of the Flaviviridae family, is a main cause of morbidity and mortality, with more than 170 million infected people worldwide. The main cause of chronic HCV in the Middle East and Egypt is HCV genotype 4 (HCV-4). Recently, HCV infection has been reported in southern Europe among immigrants, mostly from Africa, and among intravenous drug users ${ }^{1,2}$.

With $15 \%$ of the population infected, Egypt has the greatest burden of $\mathrm{HCV}$ infection in the Middle East, and HCV-4 represents $90 \%$ of the infected cases. The standard of care therapy (SOC) for HCV-4 consists of a 48-week combination therapy of pegylated interferon (PEG-IFN) $\alpha$ and ribavirin. However, only $50 \%$ of treated patients achieve a sustained virological response (SVR) $)^{3-5}$. The response to therapy and the progression of the disease to more severe liver injury are

\footnotetext{
Address to: Dr. Rania Mohammed Kishk. Microbiology and Immunology Department/Faculty of Medicine, Suez Canal University, Ismailia, Egypt. Phone: 20641025099921

e-mail: rankishk@yahoo.com

Received 5 February 2014

Accepted 11 April 2014
}

determined by many factors, including host (immunologic and genetic) and viral factors ${ }^{6}$. Genetic analysis of different cytokines, chemokines and receptors that are implicated in $\mathrm{HCV}$ pathogenesis has revealed many HCV-related polymorphisms ${ }^{7}$.

Interleukin (IL)-18, which was previously known as the interferon (IFN)- $\gamma$ inducing factor, belongs to the IL-1 cytokine family and is a proinflammatory cytokine with broad biological effects ${ }^{8-10}$. IL-18 is produced mainly by monocytes and macrophages. Together with IL-12, IL-18 enhances IFN- $\gamma$ production. Other major immunomodulatory functions for IL-18 include the stimulation of naïve $\mathrm{T}$ cells to differentiate into $\mathrm{T}$ helper 1 cells, thereby enhancing $\mathrm{T}$ cell and natural killer cell cytotoxicity (Fas/Fas ligand and perforin-mediated cytotoxicity) and modulating immunoglobulin production by B cells. IL-18 activity results in the production of a wide range of inflammatory mediators, such as nitric oxide (NO) and cytokines (e.g., TNF $\alpha$ ), that mediate the proinflammatory actions of IL-18. This activity can also be attributed to the upregulation of macrophage recruitment chemokines, e.g., IL-8, macrophage inflammatory protein (MIP-1 $\alpha$ ), MIP-1 $\beta$ and monocyte chemoattractant protein (MCP-1) $)^{8,11,12}$.

IL-18 serum levels were shown to increase in chronic hepatitis $\mathrm{C}$ patients compared to non-infected healthy people, and the serum levels were strongly correlated with the alanineaminotransferase (ALT) serum activity ${ }^{13,14}$. Three main genetic 
variants in the promoter region of the IL-18 gene have been described by Giedraitis and colleagues ${ }^{15}$. Two of these IL-18 promoter variants (-137 and -607) showed evidence of a functional relevance. A change in the HATF1 transcription factor binding site to a binding site for another factor found in the granulocyte-macrophage colony-stimulating factor (GM-CSF) promoter resulted from a $-137 \mathrm{G}>\mathrm{C}$ conversion in this gene. Similarly, the $-607 \mathrm{C}>\mathrm{A}$ promoter variant disrupts the binding site for a cAMP-responsive protein. IL-18 variants have been associated with various chronic inflammatory conditions and viral diseases, such as hepatitis $\mathrm{B}^{16}$ and Alzheimer's disease ${ }^{17,18}$.

The Egyptian population is a unique population to study $\mathrm{HCV}$ infection due to the high prevalence and predominance of HCV-4. Recently, several studies have focused on the role of the IL-28B polymorphism as a predictor of antiviral treatment in chronic $\mathrm{HCV}$ genotype 1 and $4(\mathrm{HCV}-1,4)$ patients. The objectives of the present study were the following: I) To determine and compare the IL-18 (rs1946518) genotype distributions between chronic HCV-4 patients and healthy individuals in Egypt. II) To investigate the impact of IL-18 (rs 1946518) gene polymorphisms in HCV-4 patients in response to SOC combination therapy or fibrosis progression.

\section{METHODS}

\section{Patients}

A total of 123 chronic HCV patients were enrolled in the present study. Patients were eligible for antiviral treatment according to the Egyptian treatment guidelines for $\mathrm{HCV}$. To collect demographic data, the patients and controls were interviewed using a standardized questionnaire. Demographic data included age at the start of therapy, gender and residence.

\section{Controls}

A total of 123 apparently healthy adult volunteer blood donors from the same geographical regions who had no previous complaints of liver disease and were serologically negative for hepatitis B virus (HBV), hepatitis $\mathrm{C}$ virus (HCV), and human immunodeficiency virus (HIV) served as controls. All patients and healthy subjects provided written informed consent before being enrolled in the study.

\section{Serology}

Venous blood was collected from patients, and serum was separated and stored at $-80^{\circ} \mathrm{C}$. A third-generation enzyme-linked immunosorbent assay(ELISA) kit (Diasorin, Italy) was used to detect antibodies against HCV. Elevated liver enzymes alanine aminotransferase (ALT) and aspartate aminotransferase (AST) for at least 6 months with positive serology for $\mathrm{HCV}$ were the main diagnostic criteria. Both hepatitis B surface antigen and HIV-Ab were negative in all patients by enzyme immunoassay (Diasorin, Italy). Screening for antischistosomal antibodies was performed using the indirect hemaglutination (IHA) test according to the manufacturer's instructions (Fumouze Diagnostics, France).

\section{HCV hepatitis C virus-polymerase chain reaction and genotyping}

Hepatitis $\mathrm{C}$ virus (HCV) ribonucleic acid (RNA) was detected using a quantitative real-time reverse transcription polymerase chain reaction (RT-PCR) assay (Artus HCV RG RT-PCR, Qiagen, Hilden, Germany). A line probe assay (INNOLiPA HCV II Kit, InnogeneticsQ2, Ghent, Belgium) was used to determine the genotype of the amplified HCV-complementary DNA (cDNA).

\section{Histological examination}

A percutaneous liver biopsy was performed on all patients before treatment. The modified Ishak scoring system was used to determine the stage of hepatic fibrosis and grade of inflammation.

\section{Dose of PEG-IFN and RBV}

A combination of Pegylated interferon (PEG-IFN) $\alpha$ and ribavirin (RBV) administered for 48 weeks was used as the SOC therapy for all patients. PEG-IFN was subcutaneously injected near the umbilicus in a single weekly dose of $180 \mu \mathrm{g}$ for IFN $\alpha-2 \mathrm{a}$ and $1.5 \mathrm{ug} / \mathrm{kg}$ body weight for interferon gamma (IFN- $\alpha$ )- $2 \mathrm{~b}$ together with RBV (either 1,000-1,200mg/day with IFN $\alpha$-2a or $800-1,400 \mathrm{mg} /$ day with IFN $\alpha-2 b$, depending on body weight).

\section{Treatment outcomes}

Patient outcomes following combination therapy were classified according to the clearance or recurrence of hepatitis $\mathrm{C}$ virus-ribonucleic acid (HCV-RNA) into the following groups: sustained virological response (SVR) (negative for HCV-RNA 6 months after the end of treatment), transient virological response (TVR) (negative for HCV-RNA at the end of treatment with recurrence afterwards) or null virological response (NVR) (less than a 2-log unit decline in the serum level of HCV RNA from the pretreatment baseline value within the first 12 weeks and detectable viremia at week 24 after the initiation of treatment). Patients with TVR and NVR were grouped together (non-SVR) for further analysis.

\section{Genomic DNA extraction for IL-18 genotyping}

Blood was collected into ethylenediaminetetraacetic acid (EDTA) tubes. QIAamp DNA Blood Mini Kits were used to extract genomic DNA from $200 \mu$ l of whole peripheral blood according to the manufacturer's instructions (QIAGEN, Inc., Hilden, Germany). DNA quality and quantity were assessed by calculating the absorbance ratio OD $260 \mathrm{~nm} / 280 \mathrm{~nm}$ using a NanoDrop spectrophotometer (ThermoFisher, Asheville, NC).

\section{IL-18 genotyping}

IL-18 gene variant (rs1946518) 607C >A was genotyped in all samples using TaqMan SNP genotyping assays (Applied Biosystems "AB" 7500 Real-Time "PCR" system). Allelespecific labeled TaqMan MGB probes were used (FAM- and VIC-labeled). Each reaction contained $1 \mathrm{X}$ assay mix, $1 \mathrm{X}$ TaqMan Genotyping MasterMix (AB) and 20ng of template DNA in a total volume of $25 \mu \mathrm{L}$. Cycling conditions were as follows: $95^{\circ} \mathrm{C}$ for $10 \mathrm{~min}$ and 40 cycles of amplification 
consisting of $15 \mathrm{sec}$ each and $1 \mathrm{~min}$ at $60^{\circ} \mathrm{C}$. Plate reading and genotyping (by clustering) were performed using 7500 system software version 1.2.3 in the AB 7500 Real-Time PCR system.

\section{Statistical analysis}

Single nucleotide polymorphism occurrence was in accordance with Hardy-Weinberg equilibrium in both cases and controls. Data were expressed as means \pm SDs (standard deviation) for quantitative data and as numbers and percentages for qualitative data. Categorical variables such as treatment responses were compared using chi-square $(\chi 2)$ tests. Data were analyzed using Statistical Package for the Social Sciences (SPSS) for Windows version 15 (SPSS Inc., Chicago, IL, USA). Comparisons of genotype frequencies and associations of polymorphisms with liver histological severity were examined for statistical significance using $\chi 2$. Odds ratios (ORs) with 95\% confidence intervals (CIs) were calculated to assess the odds conferred by a specific allele. A result was considered statistically significant when the p-value was less than 0.05 .

\section{Ethical considerations}

All experiments were performed according to the ethical principles of the Declaration of Helsinki.

\section{RESULTS}

\section{Population characteristics}

This study was conducted on 123 patients with chronic $\mathrm{HCV}-4$; the patient age range was $18-59$ years $($ mean $=42.3$ ). Most (83.4\%) patients were older than 30 years old, and the had a male predominance $(67.5 \%)$. Table 1 shows the baseline characteristics of these patients and the healthy controls.

A histopathological assessment of the liver biopsies using a modified Ishak scoring system showed minimal fibrosis (F0 or F1 score) in $9(7.3 \%)$ patients and moderate or marked fibrosis (F2, F3 or F4) in 114 patients (92.7\%). All patients started the 48 weeks of SOC therapy. Among these patients, 56 (45.5\%) achieved an SVR, and $67(54.5 \%)$ failed to respond to treatment [11 $(8.9 \%)$ were nonresponders (discontinued therapy), and $56(45.5 \%)$ were relapsed.

\section{Relationships between treatment response and the IL-18 gene (SNP rs1946518) and clinical variables (univariate analysis)}

Among the treated patients $(\mathrm{n}=123)$, the distribution of rs 1946518 genotypes was as follows: CC $32.5 \%$, CA $51.2 \%$ and AA $16.3 \%$. Similar frequencies of the $-607 \mathrm{C}>$ A variant were found in both the patient and control groups (Table 2). No relationships were found in univariate analyses among response type and gender, age at start of therapy, fibrosis stage, inflammation grade or HCV RNA viral load (Table 3). In contrast, the relationship between the response type and the baseline ALT was significant (Tables 3 and 4). IL-18 SNP (rs1946518) genotypes showed no relationship with the mean baseline viral loads (Table 3). The genotype distributions for the IL-18 SNP (rs1946518) were similar in both the responder and non-responder patients $(\mathrm{p}=0.02)$.
TABLE 1 - Baseline characteristics of HCV-4 patients and healthy controls.

\begin{tabular}{|c|c|c|c|c|}
\hline \multirow{2}{*}{ Discrete variables } & \multicolumn{2}{|c|}{ Patients $(n=123)$} & \multicolumn{2}{|c|}{ Healthy controls $(n=123)$} \\
\hline & $\mathrm{n}$ & $\%$ & $\mathrm{n}$ & $\%$ \\
\hline \multicolumn{5}{|l|}{ Gender } \\
\hline male & 83 & 67.5 & 71 & 57.7 \\
\hline female & 40 & 32.5 & 52 & 42.3 \\
\hline \multicolumn{5}{|l|}{ Residence } \\
\hline urban & 70 & 56.9 & 68 & 55.2 \\
\hline rural & 53 & 43.1 & 55 & 44.8 \\
\hline \multirow{2}{*}{ Continuous variables } & \multicolumn{2}{|c|}{ Patients $(n=123)$} & \multicolumn{2}{|c|}{ Healthy controls $(n=123)$} \\
\hline & \multicolumn{2}{|c|}{ Mean $\pm \mathrm{SD}$} & \multicolumn{2}{|c|}{ Mean $\pm \mathrm{SD}$} \\
\hline Age (years) & \multicolumn{2}{|c|}{$42.3 \pm 9.1$} & \multicolumn{2}{|c|}{$36.5 \pm 8.7$} \\
\hline AST $($ Mean \pm SD) & \multicolumn{2}{|c|}{$46.0 \pm 26.3$} & \multicolumn{2}{|c|}{$20.4 \pm 6.6$} \\
\hline ALT $($ Mean \pm SD) & \multicolumn{2}{|c|}{$48.9 \pm 31.8$} & \multicolumn{2}{|c|}{$22.6 \pm 6.6$} \\
\hline
\end{tabular}

$\mathrm{HCV}$ : hepatitis $\mathrm{C}$ virus; SD: standard deviation; AST: aspartate aminotransferase; ALT: alanine aminotransferase.

TABLE 2 - Genotyping distributions for the IL-18 polymorphism rs 1946518 in HCV-4 patients and healthy controls.

\begin{tabular}{lrrrrrrrr}
\hline & \multicolumn{2}{c}{$\begin{array}{c}\text { Patients } \\
(\mathrm{n}=123)\end{array}$} & & \multicolumn{2}{c}{$\begin{array}{c}\text { Controls } \\
(\mathrm{n}=123)\end{array}$} \\
\cline { 2 - 3 } rs1946518 genotype & $\mathrm{n}$ & $\%$ & & & & \\
AA & 20 & 16.3 & & 26 & 21.1 & & \\
CA & 63 & 51.2 & & 58 & 47.1 & 0.878 & 0.645 (NS) \\
CC & 40 & 32.5 & & 39 & 31.8 & & \\
\hline
\end{tabular}

HCV: hepatitis C virus; IL: interleukin ; NS: no statistically significant difference; CC, CA, AA: IL 18 promotor genotypes.

The genotype distributions for the IL-18 polymorphism (rs1946518) were not significantly different among the responder, relapsed and non-responder patients $(p=0.269)$. The distribution of rs1946518 genotypes according to different treatment outcomes is shown in Table 5.

\section{DISCUSSION}

This study is the first in Egypt to characterize the impact of functional IL-18 promoter variants on treatment outcomes in chronic $\mathrm{HCV}$ patients. The -607C/A IL-18 promoter variant was not associated with the treatment response in chronic HCV-4 patients. However, Haas et al. ${ }^{19}$ showed a significant association between both the -137 and -607 IL-18 promoter variants and the treatment response in patients infected with $\mathrm{HCV}-1$. 
TABLE 3 - Association between baseline characteristics and sustained viral response/Non-sustained viral response of hepatitis C virus treatment (univariate analysis).

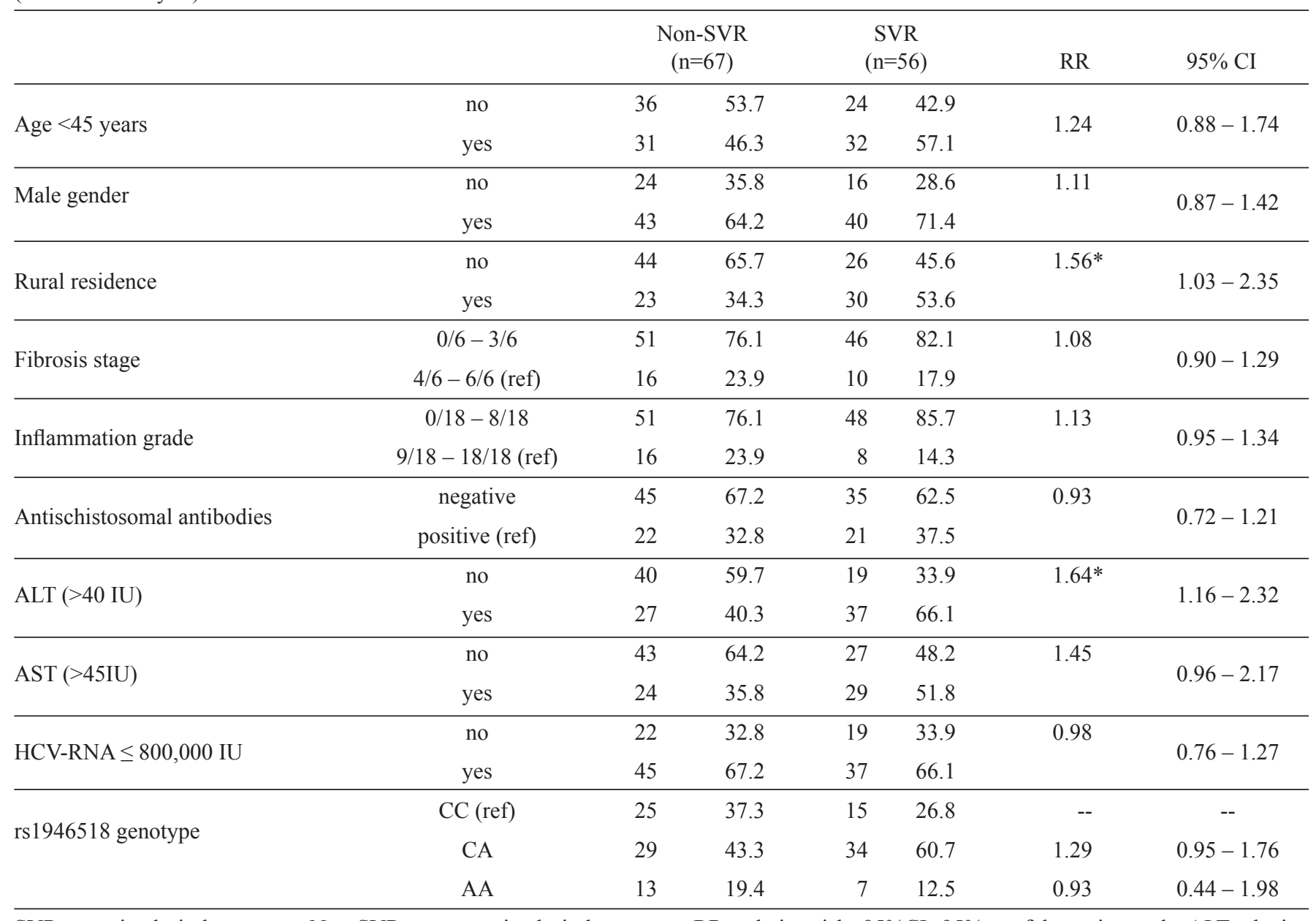

SVR: sustained viral response; Non-SVR: non-sustained viral response; RR: relative risk; 95\%CI: 95\% confidence interval; ALT: alanine aminotransferase; AST: aspartate aminotransferase; HCV-RNA: hepatitis C virus-ribonucleic acid viral load; CC, CA, AA: IL 18 promotor genotypes. *Statistically significant RR.

Together with IL-12, IL-18 is an obligatory cytokine for IFN- $\gamma$ production ${ }^{20}$. IL-18 plays a significant role in the immune response by enhancing T cell responses, regulating IFN- $\gamma$ production and promoting the development of Th1 immune responses. The treatment outcome and resolution of HCV infection have been strongly attributed to genetic host factors. HCV elimination requires a strong Th1 antiviral immune response ${ }^{19}$. This proinflammatory cytokine has a complex biological role in hepatic diseases with unclear characterization. Similar to the serum sources of IL-18, hepatic Kupffer cells, activated macrophages, Natural Killer (NK) cells and NK T cells contribute for hepatic IL-18 production ${ }^{21}$. Liver injury mediated by IL-18 can be attributed to IFN- $\gamma$ induction with the aid of IL-12. In mice primed with Propionibacterium acnes and subsequent lipopolysaccharide (LPS) challenge, the protective role of anti-IL-18 antibodies against liver damage was previusely illustrated ${ }^{10}$. In IL-18 transgenic mice, marked hepatic damage was associated with the upregulation of IL-18 expression ${ }^{21}$. However, the inhibitory effect on the replication of hepatitis B virus indicated a protective role for IL-18 during viral infections, which was explained by IFN- $\gamma$ production by hepatic NK cells and NK T cells stimulated by IL-1 $8^{22}$. Similar effects were observed in other viral mouse models ${ }^{23,24}$. Interestingly, in a monocytic cell line, IL-18 stimulated HIV replication ${ }^{25}$.

In our study, the distributions of -607C/A genotypes were not different between infected patients and healthy controls. The CA genotype was the most common genotype among the patients and the controls. Accordingly, the $\mathrm{C}$ allele was the most common allele in both patients and controls. These findings are consistent with previous studies that reported no differences in $-607 \mathrm{C} / \mathrm{A}$ genotype distributions and allele frequencies between patients and controls ${ }^{26,27}$.

Recently, Manohar et al. investigated the impact of the -607 and -137 polymorphisms on the severity of HCV infection. The -607 and -137 allelic distributions were similar in patients and controls. However, when patients were classified into 2 groups according to the severity of liver disease based on both the histological activity index ( $\mathrm{HAI} \leq 5$ or $>5$ ) and the hepatic fibrosis score ( $\leq 2$ or $>2$ ), a protective role for the IL-18 promoter 
TABLE 4 - Logistic regression analysis for predictors of the treatment outcome (SVR).

\begin{tabular}{|c|c|c|c|c|c|c|}
\hline \multirow[b]{2}{*}{ Predictors } & \multirow[b]{2}{*}{$\mathrm{B}$} & \multirow[b]{2}{*}{ SE } & \multirow[b]{2}{*}{$p$-value } & \multirow{2}{*}{$\begin{array}{c}\text { Adjusted } \\
\text { OR }\end{array}$} & \multicolumn{2}{|c|}{$95 \% \mathrm{CI}$ adjusted OR } \\
\hline & & & & & lower & upper \\
\hline Age $<45$ years & 0.266 & 0.429 & 0.535 & 1.304 & 0.563 & 3.021 \\
\hline Male gender & 0.249 & 0.437 & 0.568 & 1.283 & 0.545 & 3.020 \\
\hline Rural residence & 0.786 & 0.408 & 0.054 & 2.196 & 0.987 & 4.884 \\
\hline Fibrosis stage $(0-3)$ & -0.114 & 0.544 & 0.834 & 0.892 & 0.307 & 2.592 \\
\hline Negative antischistosomal antibodies & -0.271 & 0.432 & 0.530 & 0.763 & 0.327 & 1.779 \\
\hline $\mathrm{AST}(>45 \mathrm{IU})$ & 0.012 & 0.487 & 0.980 & 1.012 & 0.390 & 2.629 \\
\hline $\operatorname{ALT}(>40 \mathrm{IU})$ & 1.113 & 0.477 & $0.020 *$ & 3.045 & 1.195 & 7.759 \\
\hline HCV-RNA $\leq 800,000 \mathrm{IU}$ & 0.331 & 0.445 & 0.458 & 1.392 & 0.581 & 3.333 \\
\hline rs1946518 (AA) & 0.823 & 0.636 & 0.196 & 2.278 & 0.655 & 7.923 \\
\hline Constant & -1.962 & 0.809 & 0.015 & 0.141 & & \\
\hline
\end{tabular}

This model correctly predicted $64.8 \%$ of treatment outcomes. Model fit $\left(\mathrm{p}=0.048^{*}\right) ;-2 \mathrm{Log}$ likelihood $=148.5$. The only significant predictor for SVR was ALT $<40 \mathrm{IU}$; those patients had a 3-fold greater probability of developing SVR compared to patients with higher ALT levels. The AA genotype was associated with a 2.3-fold greater susceptibility to the development of SVR compared to the CC genotype, but this difference was not statistically significant. Rural residence and inflammation grades (0-8) also conferred a greater probability for SVR (2.2- and 2.0-fold, respectively), but these differences were not statistically significant. SVR: sustained viral response; B: coefficient of regression; SE: standard error of the coefficient; OR: odds ratio; $95 \% \mathrm{CI}$ : $95 \%$ confidence interval; AST: aspartate aminotransferase; ALT: alanine aminotransferase; HCV-RNA: hepatitis C virus-ribonucleic acid viral load; CC, CA, AA: IL 18 promotor genotypes.

TABLE 5 - Distribution of the rs 1946518 genotype according to different responses to SOC therapy in HCV gt-4 patients.

\begin{tabular}{|c|c|c|c|c|c|c|c|}
\hline \multirow{2}{*}{$\begin{array}{l}\text { Treatment outcomes } \\
\text { NVR }\end{array}$} & \multicolumn{6}{|c|}{ rs1946518 genotype } & \multirow{2}{*}{$\frac{\mathrm{p} \text {-value }}{\mathrm{a}}$} \\
\hline & 0 & 0.0 & 8 & 12.7 & 3 & 7.5 & \\
\hline SVR & 11 & 55.0 & 26 & 41.3 & 18 & 45.0 & (NS) \\
\hline TVR & 9 & 45.0 & 29 & 46.0 & 19 & 47.5 & \\
\hline
\end{tabular}

SOC: standard of care; HCV: hepatitis C virus; AA, CA, CC: IL 18 promotor genotypes; NVR: null virological response SVR: sustained

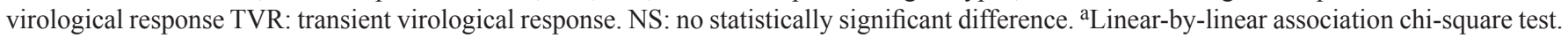

variant -607AA was evident. This finding was attributed to an association with milder forms of liver disease in chronic $\mathrm{HCV}^{27}$.

Zhang PA and coworkers studied the role of IL-18 variants -137 and -607 in HBV infection ${ }^{28}$. The authors found that a lower viral load was linked to the -607AA genotype. The same genotype was more frequently observed in $\mathrm{HCV}$ patients when compared with matched controls in a Thai population ${ }^{16}$.

In PEG-IFN and ribavirin-treated patients, serum IL-18 was highly related to the HCV-RNA titers ${ }^{29}$, serum ALT and AST activities ${ }^{30}$.

An et al. ${ }^{31}$ showed an association between the $-137 \mathrm{C}$ and -607A alleles and spontaneous clearance of HCV in African American intravenous drug users compared with those with chronic unresolved infection. Bouzgarrou et al. and colleagues ${ }^{26}$ studied the correlations among serum IL-18, HCV infection outcomes and IL-18 gene promoter SNPs $(-137 \mathrm{G} / \mathrm{C}$ and $-607 \mathrm{C} / \mathrm{A})$. A comparison of different stages and severities of $\mathrm{HCV}$ infection and IL-18 levels revealed a positive correlation with disease progression. Additionally, complicated cases with cirrhosis and hepatocellular carcinoma (HCC) were associated with the $-607 \mathrm{C}$ allele. Manohar et al. excluded the effect of IL-18 gene polymorphisms on susceptibility to chronic HCV infection $^{27}$.

In the present study, no association was found between the IL-18 promoter variant -607 and hepatic fibrosis or inflammation. Similarly, no association could be determined between this polymorphism and levels of AST or ALT. This finding is consistent with Haas et al. ${ }^{20}$ findings that the severity of hepatic inflammatory lesions, fibrosis grades and transaminase 
serum levels were not associated with either IL-18 promoter variant.

In conclusion, the IL-18 SNP rs1946518 does not affect treatment response in Egyptian $\mathrm{HCV}-4$ patients included in our study. Furthermore, no correlation was identified between this SNP and the severity of liver disease. Future studies should include more patients for more reliable assessment.

\section{CONFLICT OF INTEREST}

The authors have disclosed all financial and personal relationships with other people or organizations that could inappropriately influence or bias the work. No competing interests are declared with this article.

\section{REFERENCES}

1. Antaki N, Craxi A, Kamal S, Moucari R, Van der Merwe S, Haffar S, et al. The neglected hepatitis $C$ virus genotypes 4, 5 and 6 : an international consensus report. Liver Int 2010; 30:342-355.

2. Kamal SM. Hepatitis $C$ virus genotype 4 therapy: progress and challenges. Liver Int 2011; 31:45-52.

3. Fried MW, Shiffman ML, Reddy KR, Smith C, Marinos G, Gonçales Jr FL, et al. Peg interferon alfa-2a plus ribavirin for chronic hepatitis $\mathrm{C}$ virus infection. N Engl J Med 2002; 347:975-982.

4. Bronowicki JP, Ouzan D, Asselah T, Desmorat H, Zarski JP, Foucher J, et al. Effect of ribavirin in genotype 1 patients with hepatitis $\mathrm{C}$ responding to pegylated interferon alfa-2a plus ribavirin. Gastroenterol 2006; 131:1040-1048.

5. Paladino N, Fainboim H, Theiler G, Schroder T, Muñoz AE, Flores AC, et al. Gender susceptibility to chronic hepatitis $\mathrm{C}$ virus infection associated with interleukin 10 promoter polymorphism. J Virol 2006; 80:9144-9150.

6. Dharel N, Kato N, Muroyama R, Moriyama M, Shao RX, Kawabe T, et al. MDM2 promoter SNP309 is associated with the risk of hepatocellular carcinoma in patients with chronic hepatitis C. Clin Cancer Res 2006; 12:4867-4871.

7. Sartori M, Andorno S, Pagliarulo M, Rigamonti C, Bozzola C, Pergolini P, et al. Heterozygous betaglobin gene mutations as a risk factor for iron accumulation and liver fibrosis in chronic hepatitis C Gut 2007; 56:693-698.

8. Gracie JA, Robertson SE, McInnes IB. Interleukin-18. J Leukoc Biol 2003; 73:213-224.

9. Reddy P. Interleukin-18: recent advances. Curr Opin Hematol 2004; 11:405-410.

10. Okamura H, Tsutsi H, Komatsu T, Yutsudo M, Hakura A, Tanimoto T, et al. Cloning of a new cytokine that induces IFN-gamma production by T cells. Nature 1995; 378:88-91.

11. Nakanishi K, Yoshimoto T, Tsutsui H, Okamura H. Interleukin-18 regulates both Th1 and Th2 responses. Annu Rev Immunol 2001; 19:423-474

12. Tsutsui H, Matsui K, Okamura H, Nakanishi K. Pathophysiological roles of interleukin-18 in inflammatory liver diseases. Immunol Rev 2000; 174:192-209.

13. Vecchiet J, Falasca K, Cacciatore P, Zingariello P, Dalessandro M, Marinopiccoli M, et al. Association between plasma interleukin-18 levels and liver injury in chronic hepatitis $\mathrm{C}$ virus infection and non-alcoholic fatty liver disease. Ann Clin Lab Sci 2005; 35:415-422.
14. Jia HY, Du J, Zhu SH, Ma YJ, Chen HY, Yang BS, et al. The roles of serum IL-18, IL-10, TNF-alpha and sIL-2R in patients et al. The roles of serum IL-18, IL-10, TNF-alpha and sIL-2R in patients with chronic hepatitis C. Hepatobiliary Pancreat Dis Int 2002; 1:378-382.

15. Giedraitis V, He B, Huang WX, Hillert J. Cloning and mutation analysis of the human IL-18 promoter: a possible role of polymorphisms in expression regulation. J Neuroimmunol. 2001; 112:146-152.

16. Hirankarn N, Manonom C, Tangkijvanich P, Poovorawan Y. Association of interleukin-18 gene polymorphism (-607A/A genotype) with susceptibility to chronic hepatitis B virus infection. Tissue Antigens 2007; 70:160-163.

17. Bossu P, Ciaramella A, Salani F, Bizzoni F, Varsi E, Di Iulio F, et al. Interleukin-18 produced by peripheral blood cells is increased in Alzheimer's disease and correlates with cognitive impairment. Brain Behav Immun 2008; 22:487-492.

18. Bossu P, Ciaramella A, Moro ML, Bellincampi L, Bernardini S, Federici G, et al. Interleukin 18 gene polymorphisms predict risk and outcome of Alzheimer's disease. J Neurol Neurosurg Psychiatry 2007; 78:807-811.

19. Zecchina G, Novick M, Rubinstein V, Barak V, Dinarello C, Nagler A. Interleukin-18 binding protein in acute graft versus host disease and engraftment following allogeneic peripheral blood stem cell transplants. J Hematother Stem Cell Res 2001 Dec; 10:769-776.

20. Haas SL, Weiss C, Bugert P, Gundt J, Witt H, Singer MV, et al. Interleukin 18 promoter variants $(-137 \mathrm{G}>\mathrm{C}$ and $-607 \mathrm{C}>\mathrm{A})$ in patients with chronic hepatitis C: association with treatment response. J Clin Immunol 2009; 29:620-628.

21. Finotto S, Siebler J, Hausding M, Schipp M, Wirtz S, Klein S, et al. Severe hepatic injury in interleukin 18 (IL-18) transgenic mice: a key role for IL-18 in regulating hepatocyte apoptosis in vivo. Gut 2004; 53:392-400.

22. Kimura K, Kakimi K, Wieland S, Guidotti LG, Chisari FV. Interleukin-18 inhibits hepatitis B virus replication in the livers of transgenic mice. J Virol 2002; 76:10702-10707.

23. Fujioka N, Akazawa R, Ohashi K, Fujii M, Ikeda M, Kurimoto M. Interleukin-18 protects mice against acute herpes simplex virus type 1 infection. J Virol 1999; 73:2401-2409.

24. Tanaka-Kataoka M, Kunikata T, Takayama S, Iwaki K, Ohashi K, Ikeda M, et al. In vivo antiviral effect of interleukin 18 in a mouse model of vaccinia virus infection. Cytokine 1999; 11:593-599.

25. Shapiro L, Puren AJ, Barton HA, Novick D, Peskind RL, Shenkar R, et al. Interleukin 18 stimulates HIV type 1 in monocytic cells. Proc Proc Natl Acad Sci USA 1998; 95:12550-12555.

26. Bouzgarrou N, Hassen E, Schvoerer E, Stoll-Keller F, Bahri O, Gabbouj S, et al. Association of interleukin-18 polymorphisms and plasma level with the outcome of chronic HCV infection. J Med Virol 2008; 80:607-614.

27. Manohar K, Suneetha PV, Sukriti, Pati NT, Gupta AC, Hissar S, et al. Association of IL-18 promoter polymorphism with liver disease severity in HCV-infected patients. Hepatol Int 2009; 3:371-377.

28. Zhang PA, Wu JM, Li Y, Yang XS. Association of polymorphisms of interleukin-18 gene promoter region with chronic hepatitis B in Chinese Han population. World J Gastroenterol 2005; 11:1594-1598.

29. Murata K, Yamamoto N, Kawakita T, Saito Y, Yamanaka Y, Sugimoto K, et al. Up-regulation of IL-18 by interferon alpha-2b/ribavirin combination therapy induces an anti-viral effect in patients with chronic hepatitis $\mathrm{C}$. Hepatogastroenterology 2005; 52:547-551.

30. Falasca K, Ucciferri C, Dalessandro M, Zingariello P, Mancino P, Petrarca C, et al. Cytokine patterns correlate with liver damage in patients with chronic hepatitis B and C. Ann Clin Lab Sci 2006; 36:144-150.

31. An P, Thio C, Kirk G, Donfield S, Goedert J, Winkler C. Regulatory Polymorphisms in the Interleukin-18 Promoter Are Associated with Hepatitis C Virus Clearance. J Infect Dis 2008; 198:1159-1165. 